\title{
Transparency in the Allocation of Municipal Grants for Sports and Voucher Systems in the Czech Republic
}

\section{Marek Pavlík ${ }^{1}$}

\begin{abstract}
This paper will assess transparency in the decision-making process in sports grants allocation. In comparison with other parts of the public sector, surprisingly little is known about transparency in the sports sector. An increasing portion of public funds is spent on sport grants; this establishes the necessity for research. Can any positive effects of sports grants be expected to appear without transparency in the decisionmaking process? An examination of the process in reality is crucial for future public resources allocation. Based on the general assumption that NGOs are important actors in economic and political development, we address the Czech Republic at the municipal level.
\end{abstract}

The main goals of this paper are to assess the transparency of the allocation of public grants for sport organizations on the municipal level in the Czech Republic and to discuss one possible method for improving system transparency and efficiency: vouchers.

We discuss sport vouchers as a possible tool for improving transparency. Vouchers solve the problem of transparency in the decision-making process by transferring the purchasing power to the client. Although using sports vouchers as a tool for allocating public resources is quite rare, there are a few examples of this practice in the Czech Republic. We established two research questions: (1) Do sport clubs perceive the allocation of sport grants at the municipality level as transparent? (2) Do sport clubs consider a voucher system as helpful for the transparency? To answer these questions, we discuss the theory and specific conditions in the Czech Republic; we perform a survey among sport clubs and we examine examples of voucher implementation; and we discuss the general consequences of our results.

Key words: Public sector; public finance; grants; sport; NGO; allocation rules; municipality; transparency, vouchers

JEL Classification: H76, L3, L83

${ }^{1}$ Masaryk University, Faculty of Economics and Administration, Lipová 41a, Brno 602 00,pavlik@econ.muni.cz 


\section{Introduction}

Transparency in the allocation of public grants is important topic in most democratic countries. The post-communist European countries face problems of transparency as well as corruption in various parts of the public sector (see Transparency International's 2011 annual report). This paper will investigate transparency in the decision-making process in sports grants allocation. In comparison with other parts of the public sector, surprisingly little is known about transparency in the sports sector.

An increasing portion of public funds is spent on sports grants; this establishes the necessity for research. The EU believes that "in grassroots sport, equal opportunities and open access to sporting activities can only be guaranteed through strong public involvement" (Commission of the European Union; p. 13, 2007a). Can any positive effect be expected to appear without transparency in the decision-making process?

Exploring the reality is crucial for future public resources allocation. Research results have raised arguments against the support of sport activities/organizations from public budgets because little or no positive economic impacts were proved (e.g. MARTIN 2001, JONES 2002) and the process of grants allocation is more a political than a rational economic process (KANTOR 1995). There are at least three possible perspectives on the problem of grants allocations for sports organizations: 1) grants are useful and benefit society; it is also a traditional part of state activities; 2) grants can be useful and benefit society under specific circumstances; 3) grants have no real effect, it's a kind of a fiscal illusion; grants are the result of political decisions without connections to any economic or non-economic benefit for society. If there are to be any positive effects, the transparency of the decision-making process is a necessary condition (Stirton \& Lodge, 2001). Based on the general assumption that NGOs play important roles in economic and political development (Brown \& Kalegaonkar, 2002), we address the situation at the municipal level in the Czech Republic which is usually perceived as a partner of NGOs.

The main goals of the paper are to assess the transparency of the allocation of public grants for sports organizations on the municipal level in the Czech Republic and to discuss one possible method of improving transparency: a vouchers system.

The evidence that there is a transparent environment in grants allocation does not mean that the positive effect on society automatically appears... but it is one of the key conditions. If the Czech Republic fails in the field of sports grants allocation transparency, we can seriously doubt the positive effects of grants in the other postcommunist countries. Examining this key condition is one step on the way to answering "What should we do with grants for sport? How should we allocate them? Which criteria should be relevant?" Without answers to these questions, the continuation of public grants allocation is like playing tennis blindfolded and being surprised when the ball is not hit.

Wolman and Spitzley (1999) recommended that future research should focus on participants and their interests in a conflict and on how the conflict is resolved. Our research adds the problem of transparency as a variable affecting participant behaviour and wider policy outcomes (positive effects for society). We discuss sports vouchers as a possible tool for improving transparency. The use of vouchers in public resources allocation was originally introduced in the education system. One of the earliest 
suggestions for the government use of vouchers, made by (Friedman, Friedman, 1982), was as a way to fund education without excessive government intervention in the education market. Vouchers typically transfer purchasing power to the client.

The healthcare sector is another possible voucher market that has been extensively explored. Health vouchers could be used as a tool for increasing patient choice in healthcare providers or targeting subsidies to the poor and/or high risk and vulnerable groups (see more in Gorter et al 2003), and well-structured vouchers may provide transparent funding of healthcare services (Wilson 1999; Peacock \& Segal 2000). The use of sports vouchers as a tool for public resource allocation is quite rare, though early attempts were made in the USA and there are examples of sports vouchers in the Czech Republic. Crompton (1983) noted that "there is a danger that resources may be allocated to the most persuasive rather than the most responsive organizations". Valkama \& Bailey (2001) categorise sport vouchers as service vouchers within the public sector; however, they see vouchers as a useful tool for employers to motivate/reward employees. Their taxation of vouchers enables the possibility of using vouchers as an allocation tool similar to school vouchers.

The vouchers represent a possible answer to the transparency problem. Neither transparency nor the voucher system has yet been researched in the sport sector. We established two research questions:

- $\quad$ Do sport clubs perceive the allocation of sport grants at the municipality level as transparent?

- What are the (dis)advantages of the voucher system in the opinions of sport clubs, and what is the practice of municipalities which use the voucher system for sport grant allocation?

To answer these questions, we discuss the theory and specific conditions in the Czech Republic; we perform a survey among sport clubs and examine examples of the voucher system implementation; and we discuss the general consequences of our results.

\section{Public financing of sport organizations in the Czech Republic}

There are many opportunities for Czech sport organizations to receive some kind of grant (see Table 1); however, each decision about grant allocation should be based on the same principle: the application of definite examination rules which respect the goals of the sport policy. The sports organizations are not only non-governmental; they can also be for-profit organizations. The following analysis is focused only on NGO sport organizations for two reasons: (1) with the exception of some professional sports clubs, the NGO legal form has a strong majority, particularly due to tax preferences; and (2) the non-profit legal form is usually a condition for grants, especially at the municipal level. 
Table 1: Review of sport NGOs and their public sector partners

\begin{tabular}{|c|c|c|c|}
\hline $\begin{array}{c}\text { Type of sport } \\
\text { NGO }\end{array}$ & Description & Subsidizer & $\begin{array}{c}\text { Decision } \\
\text { maker }\end{array}$ \\
\hline $\begin{array}{l}\text { General Sport } \\
\text { Associations } \\
\text { (GSA) }\end{array}$ & $\begin{array}{l}\text { There are nine GSAs which } \\
\text { encompass all sport branches } \\
\text { unions/federations in the Czech } \\
\text { Republic. These nine were } \\
\text { stakeholders of the biggest } \\
\text { lottery company in the Czech } \\
\text { Republic. Their role consists of } \\
\text { providing financial and non- } \\
\text { financial support for sport } \\
\text { unions/federations. It seems that } \\
\text { their role has been decreasing } \\
\text { since } 2011 \text {. }\end{array}$ & $\begin{array}{l}\text { Ministry of } \\
\text { Education, } \\
\text { Youth and Sport } \\
\text { Ministry of } \\
\text { Defence } \\
\text { Ministry of the } \\
\text { Interior } \\
\text { EU } \\
\text { funds/projects }\end{array}$ & $\begin{array}{l}\text { Ministry } \\
\text { committee }\end{array}$ \\
\hline $\begin{array}{l}\text { Sport branch } \\
\text { federations / } \\
\text { unions / } \\
\text { associations }\end{array}$ & $\begin{array}{l}\text { Members of one of the GSAs. } \\
\text { Each sport union/federation } \\
\text { incorporates sport clubs in the } \\
\text { given sport branch. These } \\
\text { unions/federations can be divided } \\
\text { into regional sub- } \\
\text { unions/federations. }\end{array}$ & $\begin{array}{l}\text { Regional } \\
\text { municipalities } \\
\text { Ministry of } \\
\text { Education, } \\
\text { Youth and Sport } \\
\text { EU } \\
\text { funds/projects }\end{array}$ & $\begin{array}{l}\text { Representative } \\
\text { body }\end{array}$ \\
\hline Sport clubs & $\begin{array}{l}\text { Basic unit. Most sport clubs are } \\
\text { NGOs; however, some of them } \\
\text { operate as ltds, joint stock } \\
\text { companies, or sole proprietors. }\end{array}$ & $\begin{array}{l}\text { Regional and } \\
\text { local } \\
\text { municipalities } \\
\text { EU } \\
\text { funds/projects } \\
\text { Sport federation/ } \\
\text { association }\end{array}$ & $\begin{array}{l}\text { Representative } \\
\text { body }\end{array}$ \\
\hline
\end{tabular}

Source: author

The role of municipalities in the process of subsidizing sport NGOs is all the more important because sport NGOs receive grants and non-financial support from municipalities more frequently than they receive support from their own sport federation/association; see Figure 1. Our study shows important information about the failing system of internal support within the sport federation. It could be expected that the internal support system within the sport federation and association would be more supportive and generous than municipal support. However, sport federations can also be recipients of public grants; the only difference is the system of redistribution. Nemec et al (2000) showed that there is a risk of high dependence on public budgets for sport clubs in the Slovak Republic. 
Figure 1: Comparison of support received from local municipalities and sport federations (in percentage of respondents 2011)

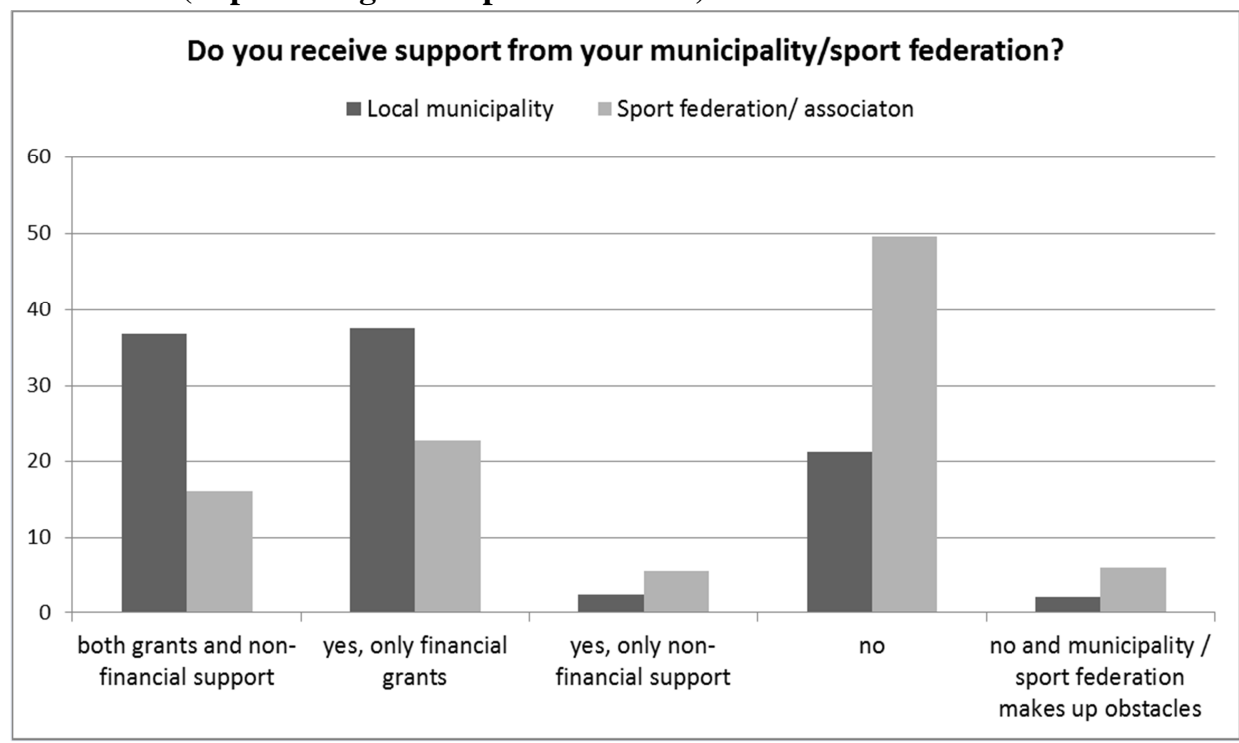

Source: author

In the following text, we focus mainly on sport organizations and their relations and experiences with government at the local level. This step allowed us to compare the declared attitude of municipalities with sport clubs' opinions and experiences.

\section{Research methodology}

The results are based on two separately performed analyses. The first analysis presents the results of our survey among sport clubs. The second analysis involved examples of sport voucher implementation in the Czech Republic.

\section{Questionnaire research among sport clubs}

This is the key part for assessing the difference between declared principles and reality as perceived by sport clubs. The questionnaire research was conducted among sport clubs in the Czech Republic in spring 2011. A list of 19 questions was sent to 1567 sport clubs; 430 completed forms were returned. Of those 430 respondents, 406 were listed as having a non-profit legal form. It is difficult to estimate the total number of sport organizations in the Czech Republic, hence we cannot evaluate if the answers were enough for a representative sample. The questionnaire was sent to approximately $60 \%$ of the sport organizations enrolled in the Czech Sports Association (ČSTV). ČSTV includes 72 sport federations and it is estimated that $70 \%$ of athletes are members of the ČSTV.

We estimated that the 430 respondents represent approximately 58,000 registered members of sport clubs. However, there are an estimated 2.5 million members of sport 
organizations. We analysed responses to six questions: (1) "Did you receive support ${ }^{2}$ from your municipality?"; (2) "Did you receive support from your sport federation/association?"; (3) "How should grants be allocated?"; (4) "How are grants allocated in reality?"; (5) "Have you noticed any problems with corruption in relation to sport grants allocation?"; and (6) "What do you think about using vouchers for the allocation of grants?"

Respondents (sport clubs) had the opportunity to answer a question about how grants should be allocated. They were allowed to choose more than one answer, and their contributions to the final percentage were calculated on the principle that one club has one suffrage; thereby, if there were four possible answers, each answer was calculated as one quarter for each category. All answers were anonymous.

\section{Analysis of examples of voucher systems used for sport grants at the municipal level in the Czech Republic}

We gathered information about three municipalities which had implemented voucher systems and one municipality with a proposed voucher system. All information was verified in September 2012 through publicly available documents.

\section{Research results}

The results show an unsatisfactory situation in the Czech Republic. The questionnaire revealed that $76 \%$ of sport clubs regularly apply for grants. All answers indicated that respondents expect transparency, i.e. clear criteria which are crucial for grants allocation. The option of an open-ended answer was never used for expressing a preference for any kind of clientelism or corrupt activities. Most sport organizations expect definite criteria for grants allocation (see. Fig.2). As with other answers, we see the typical conflict of evaluating the criteria. What is most important: the number of youth, the number of members, the popularity of the sport, or something else?

Figure 2: How should grants be allocated (opinion of sport clubs in 2011)?

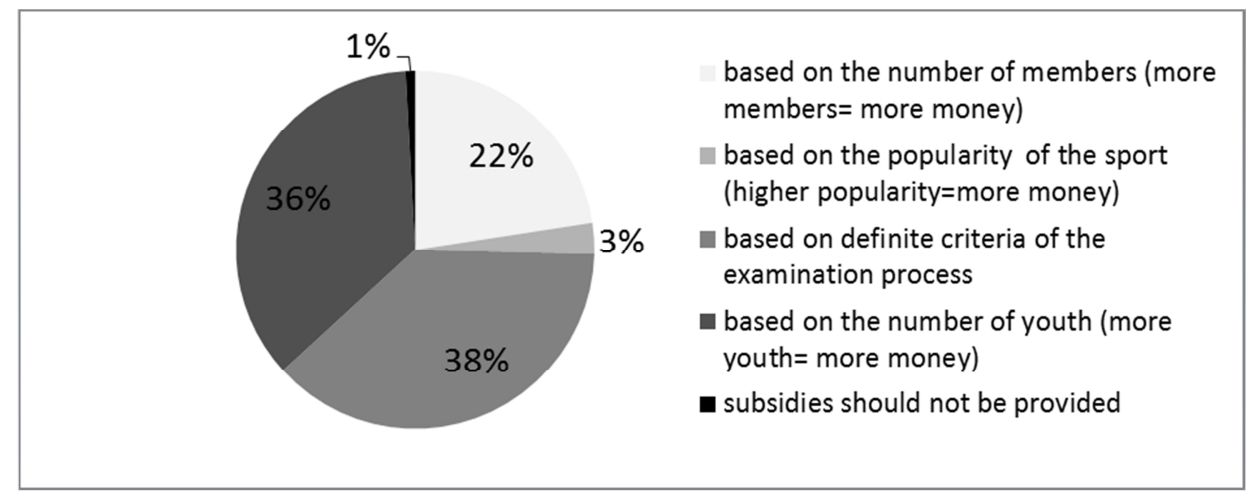

Source: author

${ }^{2}$ Support means financial grants and/or non-financial support 
The question of how grants are allocated in reality was asked of all the sport clubs, not only those that had applied for grants in the previous two years; see Figure 3. There are two reasons for this:

- The sport club could have its own experience from more than two years ago.

- The sport club could be informed by other sport clubs. When we calculated the results only for those sport clubs that applied for grants in the previous two years, there was no significant difference.

Figure 3: How are grants allocated in reality (opinion of sport clubs in 2011)?

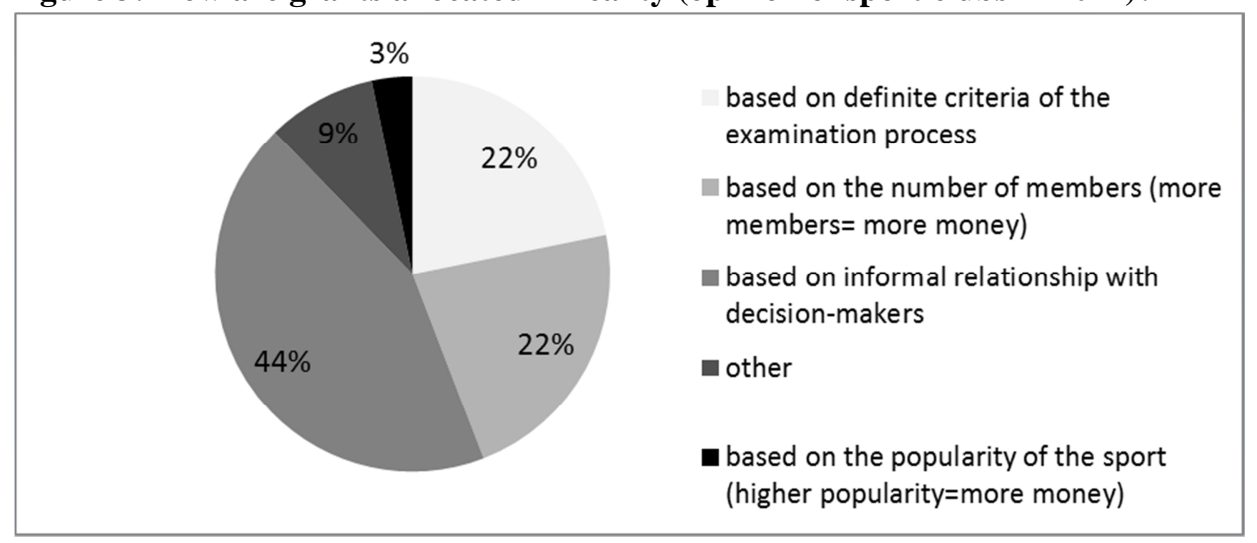

Source: author

Sport organizations have to provide a lot of information about themselves and about the purpose of their grant application, but in most cases they have no information about the examination criteria and preferred allocation alternatives. This situation inevitably leads to a point where the majority of potential recipients begin to perceive the process as non-transparent and potentially corrupt.

The decision-making process usually involves three steps: (1) A hearing with the sport (or education) committee which is an adviser for the municipal body. The committee usually concludes the hearing with some recommendations for the council and the representative body of the municipality. This hearing is not open the public. (2) The proposal submitted by the committee is discussed by the council of the municipality and it is concluded with recommendations for the representative body. This process also does not permit public access. (3) The representative body makes a decision, usually in accordance with the recommendations of the council and the committee. The results of the decision-making process are then announced. 


\section{Corruption}

Although respondents perceive the system as a non-transparent, only $13.3 \%$ reported a direct experience of corruption. In combination with symbolic ${ }^{3}$ corruption, we can estimate that at least $30 \%$ of respondents had to face a non-transparent environment; see Table 4 . The absence of corruption does not mean that the system can be considered as transparent.

Table 4: Have you noticed a problem with corruption in relation to sport grants?

\begin{tabular}{|l|r|r|}
\hline Answer & \multicolumn{1}{|c|}{ Number } & \multicolumn{1}{|c|}{$\%$} \\
\hline Yes & 57 & 13.3 \\
\hline Yes, but symbolic rather than effective corruption & 75 & 17.4 \\
\hline No & 298 & 69.3 \\
\hline Total & 430 & 100.0 \\
\hline
\end{tabular}

Source: author

\section{Vouchers - opinion of sport clubs}

The question about vouchers as a possible solution to the transparency problem was presented without additional information for respondents. We thus have to evaluate the results taking into account the possibility that some of respondents had no knowledge of the voucher system.

Figure 4: Using vouchers for grants allocation (opinion of sport clubs in 2011)

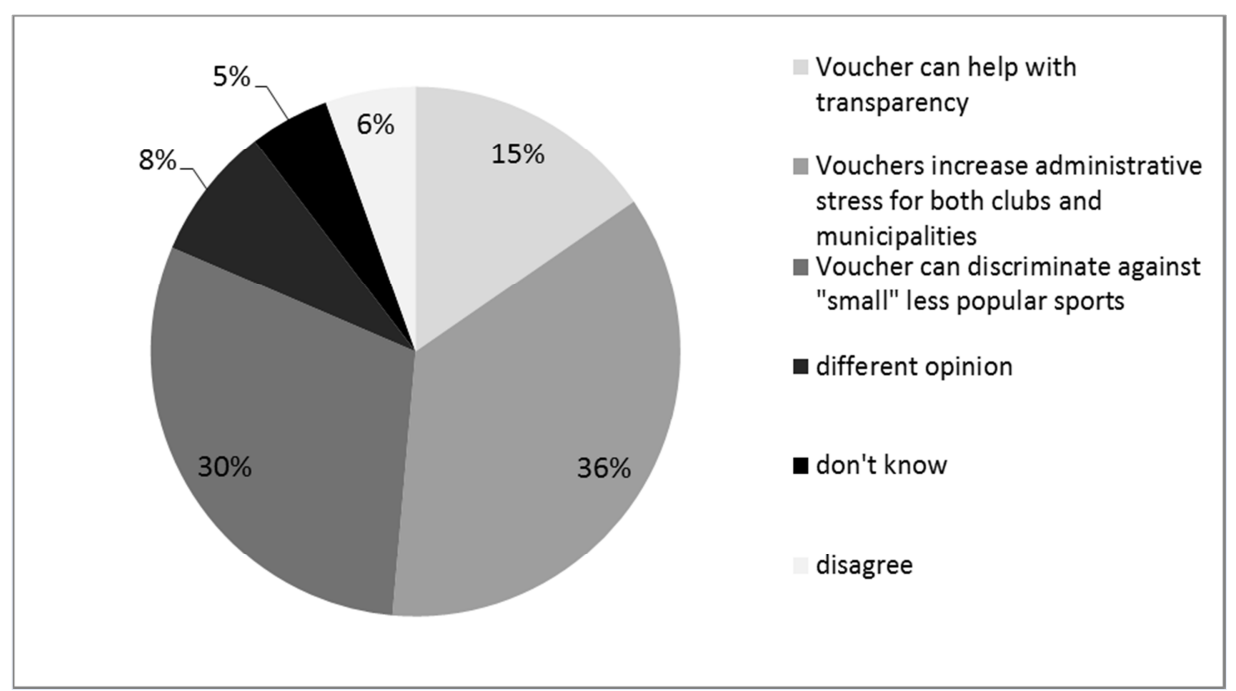

Source: author

\footnotetext{
${ }^{3}$ In this case, the term "symbolic corruption" refers to the situation when decision makers receive gifts (before or after deciding) that could be considered as reciprocal. The word "symbolic" refers to the fact that the gift is usually of little financial value (like a bottle of whiskey or a box of chocolates).
} 
The surprising opinion that vouchers could discriminate against clubs participating in less popular sports has strong roots. We can see normative issue behind this answer. If a sport is popular, then it has better access to private resources and therefore a less popular sport (but also producers of positive externalities i.e. health, lifestyle) should be supported. On the other hand, if a sport is popular, it means that people are interested in this sport and therefore it is reasonable to support it. The problem is obvious in the case of vouchers: less popular sports have fewer members and hence they receive fewer vouchers.

Considering actual experiences with corruption and the opinions of sport clubs on how grants are actually allocated, we find interesting differences in the opinions of sport clubs that support the idea of the voucher system. The first result can be seen in Fig. 5, where "voucher supporters" more often perceived grant allocation as a result of informal relationships with the decision-makers. Experience with corruption is also higher in the group of "vouchers supporters" (See Table 5).

\section{Figure 5: Opinions of sport clubs on the voucher system in percentage in 2011}

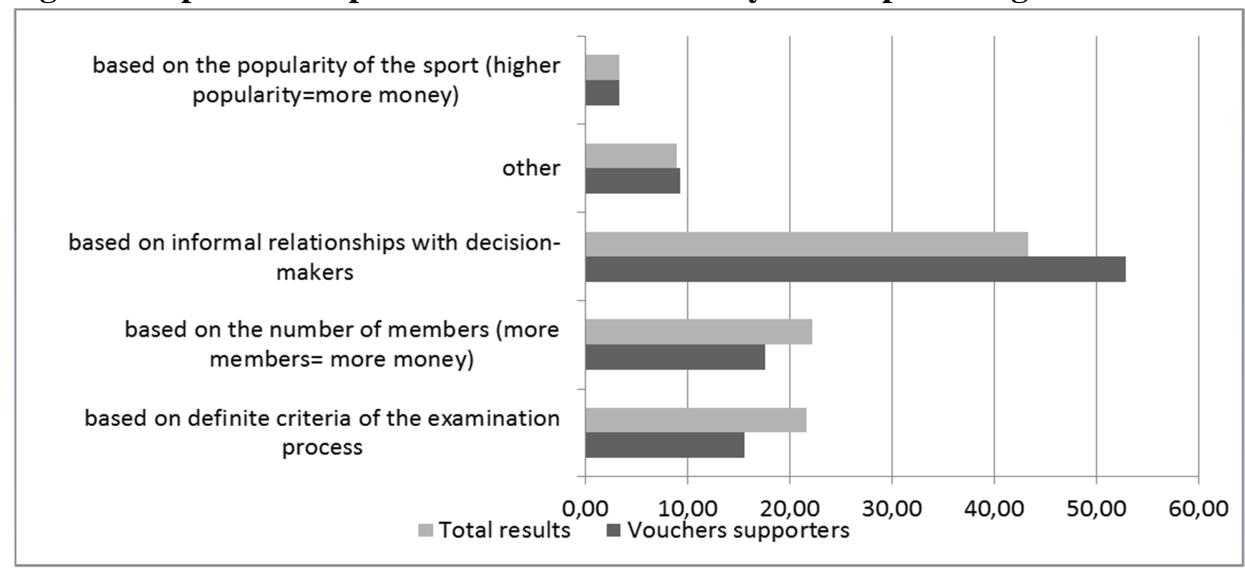

Source: author

Table 5: Experiences of sport clubs with corruption

\begin{tabular}{|l|c|c|c|c|c|}
\hline $\begin{array}{c}\text { Have you noticed any } \\
\text { problems with } \\
\begin{array}{c}\text { corruption in relation to } \\
\text { sport grants? }\end{array}\end{array}$ & \multicolumn{2}{|c|}{$\begin{array}{c}\text { Vouchers } \\
\text { supporters }\end{array}$} & \multicolumn{2}{c|}{ Total results } & Difference \\
\hline Yes & 11 & 14,67 & 57 & 13,26 & 1,41 \\
\hline $\begin{array}{l}\text { Yes, but symbolic rather } \\
\text { than real }\end{array}$ & 16 & 21,33 & 75 & 17,44 & 3,89 \\
\hline No & 48 & 64,00 & 298 & 69,30 & $-5,30$ \\
\hline Total & 75 & $\%$ & 430 & $\%$ & \\
\hline
\end{tabular}

Source: author 


\section{Vouchers for sport in the Czech Republic}

The idea of vouchers used for grant allocation is not new in the Czech Republic. The following list presents the practice of selected municipalities where part of the total financial resources dedicated to sport is allocated to voucher programs.

The voucher system has been implemented in three cities: Hodonín, with 25 thousand inhabitants and the longest tradition in voucher system (since 2008), Opava (58 thousand inhabitants), and Poděbrady (almost 14 thousand inhabitants). One city (Prostějov, ${ }^{4}$ with 44 thousand inhabitants) is considering implementing the voucher system. Each city created its own system; however, we can find similarities. The voucher system is based on the following principles in all these cities: the person with the right to the voucher has to visit the municipal office and pick up the voucher; the voucher (one or all parts) is given to the sport club preferred by the voucher bearer; and the sport clubs submit the vouchers to the municipality, on the basis of which they receive financial support. However, Opava (Opava 2013) bypassed the first step; the prospective recipient can print the voucher and give it to the sport club. The municipality is responsible for duplicity check.

The value of the voucher can be set explicitly before distribution (Prostějov) or derived from the total amount dedicated to subsidies and the number of vouchers presented by the sport club (Hodonín - ex post 85 euro per voucher in 2012; Opava). Based on the information available, the value of vouchers allocated for one child (recipient) is 40-100 euro per year. Although vouchers are usually considered to be more transparent than the standard grant system, we noticed some difficulties when seeking information about vouchers on the web pages in these cities. Some information (e.g. the number of received vouchers, the number of supported children) was not easy to find. We also found some information unclear from the point of view of the sport club. Ex ante determination of the voucher value is probably more transparent for sport clubs; however, from the point of view of the municipality, it can cause surplus budget issues.

All the cities use vouchers as a supplementary method for allocating financial support for selected groups of recipients. However, in some cases, if a club receives a direct grant from the municipality budget, then it is excluded from the voucher system $\left(\right.$ Opava $\left.^{5}\right)$. Other differences can be found in the system variables.

The first variable in the voucher system is the target group as defined by the age of the prospective recipient. Hodonín ${ }^{6}$ and Opava enabled vouchers only for the age group ranging from 6 to 18 (19) years; Poděbrady does not apply any age restriction. An alternative approach of the cities can be seen also in the possibility to get the voucher even if the recipient does not have a permanent address in the city (Hodonín).

Another variable is the divisibility of the voucher into parts (Hodonín and Opava enable division into two parts, Poděbrady ${ }^{7}$ into three parts). The divisibility of the voucher means that each part of the voucher can be given to different organizations or all parts

\footnotetext{
${ }^{4}$ Bursa 2012

${ }^{5}$ Opava (2012; 1), Opava (2012; 2), Opava (2013;1)

${ }^{6}$ Hodonín (2012; 1), Hodonín (2012; 2), Hodonín (2012; 3), Hodonín (2012; 4)

${ }^{7}$ Poděbrady 2012;1

52
} 
can be given to one subject only. Table 6 summarizes the available data about the practice in the municipalities presented.

Table 6: Main differences among the voucher system in analysed municipalities

\begin{tabular}{|l|l|l|l|l|l|}
\hline \multicolumn{1}{|c|}{ City } & $\begin{array}{l}\text { Determination } \\
\text { of the value } \\
\text { of voucher }\end{array}$ & $\begin{array}{l}\text { Expenditure } \\
\text { on one } \\
\text { recipient in } \\
\text { CZK (2012) }\end{array}$ & Target group & $\begin{array}{c}\text { Number of } \\
\text { parts }\end{array}$ & $\begin{array}{c}\text { Number of } \\
\text { supported } \\
\text { recipients } \\
\text { (2012) }\end{array}$ \\
\hline Hodonín & $\begin{array}{l}\text { Floating } \\
\text { (ex post) }\end{array}$ & 2118 & Age 6-18 & 2 & $875(2009)$ \\
\hline Opava & $\begin{array}{l}\text { Floating } \\
\text { (ex post) }\end{array}$ & 1000 & Age 6-19 & 2 & 966 \\
\hline Poděbrady & $\begin{array}{l}\text { Floating } \\
\text { (ex post) }\end{array}$ & NA & No age limit & 3 & N/A \\
\hline $\begin{array}{l}\text { Prostějov } \\
\text { (proposal) }\end{array}$ & $\begin{array}{l}\text { Fixed } \\
\text { (ex ante) }\end{array}$ & - & Age 6-19 & 2 & - \\
\hline
\end{tabular}

Source: author

\section{Summary of findings}

We identify a lack of transparency and showed potential space for the voucher system as a tool for increasing transparency. Only 23\% of respondents stated that grant allocation is done according to clear criteria (methodology). Another important finding is that almost $30 \%$ of respondents experienced some form of corruption. Despite unpromising finds, we proved that there is a relatively good relationship between clubs and municipalities (at least in comparison with relationship with sport federations). The role of municipalities in sport support has a long tradition and cooperation with nonprofit organization is a part of modern society.

The vouchers system may be a part of this relationship. We discovered that the sport clubs have a somewhat skeptical position, and we would probably discover the same opinion from municipalities. However, most of this skepticism could result from insufficient information.

Based on analysis of the voucher systems in municipalities where the system has come into practice, we created the summary provided in Table 7 . We assume that the voucher system may be more transparent; however, it probably increases the total administrative stress for the municipality, sport clubs, and the citizens in the target group of the voucher program. But the example of Opava showed that this administrative stress can be minimized and transferred to the municipality. All municipalities use the voucher system together with the grant system based on requests by clubs, whilst the decision is made by the municipality body. 
Table 7: Advantages and disadvantages of vouchers in sport

\begin{tabular}{|c|c|c|}
\hline & Advantages (benefits) & Disadvantages (costs) \\
\hline Recipients & $\begin{array}{l}\text { - Motivation to continue or } \\
\text { start with sport } \\
\text { - Freedom of consumer choice } \\
\text { - Indirect involvement in } \\
\text { public affairs }\end{array}$ & $\begin{array}{l}\text { - Time (and cost) for collecting the } \\
\text { voucher from the local municipality }\end{array}$ \\
\hline $\begin{array}{l}\text { Sport clubs } \\
\text { /organization }\end{array}$ & $\begin{array}{l}\text { - Increasing interest in services } \\
\text { granted by the voucher } \\
\text { - Guaranteed support not } \\
\text { dependent on a political } \\
\text { decision-making process }\end{array}$ & $\begin{array}{l}\text { - Administrative stress } \\
\text { - Economic costs of administration } \\
\text { - The risk that no public resources } \\
\text { would be gained if no vouchers } \\
\text { from members were gathered } \\
\text { - Vouchers are set to a fixed amount } \\
\text { of money, hence cost differences } \\
\text { among sports are not taken into } \\
\text { consideration } \\
\text { - The value of the voucher can be } \\
\text { floating (derived from the number } \\
\text { of collected vouchers), and thus the } \\
\text { sum of money can be unpredictable }\end{array}$ \\
\hline $\begin{array}{l}\text { State / local } \\
\text { municipality }\end{array}$ & $\begin{array}{l}\text { - Establish a transparent } \\
\text { system based on inhabitants' } \\
\text { revealed preferences instead } \\
\text { of on a political decision } \\
\text { - Absence of the necessity to } \\
\text { formulate a clear sport grant } \\
\text { policy - consumer choice } \\
\text { determines allocation }\end{array}$ & $\begin{array}{l}\text { Direct economic cost: } \\
\text { - Costs of distribution of vouchers } \\
\text { - Increasing of administrative stress } \\
\text { especially if vouchers are used in } \\
\text { combination with the previous } \\
\text { system } \\
\text { Other impacts } \\
\text { - Vouchers cannot be used in } \\
\text { investment decisions }\end{array}$ \\
\hline
\end{tabular}

Considering opinions of sport clubs we identified three important variables:

- Vouchers may increase transparency

- Vouchers may induce new administrative stress

- Vouchers may discriminate against "small sports"

The administrative stress can be minimized through a benchmark of voucher systems already implemented. And the problem of "small" sport clubs/branches (i.e. less popular sports or clubs with a small number of members) can be solved (if it is the preference of a municipality) by the grant system based on the request and decision-making process of a municipality body. Or we can accept the premise that clubs with more members (inhabitants of the municipality) gather more vouchers and hence they have right to receive higher financial support. 


\section{Conclusion}

We investigated the opinions of sport clubs related to the problems of transparency, including corruption, and to a possible solution - the voucher system. Without transparency, any positive effects for society induced by grants for sport organizations can hardly be expected. Information was collected via a questionnaire given to 430 sport clubs during spring 2011. We found a critical lack of transparency in the decisionmaking process in the Czech Republic. In other words, we played tennis blindfolded and we missed the ball.

The analyses performed showed serious problems with the transparency of the decisionmaking process. However, we found that at least some information about general grant principles is available, which is encouraging. We could anticipate that transparency problems are closely related to the availability of publicly displayed information provided by the municipality (i.e. granting principles, methodology of decision-making, review of allocated grants). Considering the increasing portion of public resources spent on sport, we pointed out the necessity of research. We are convinced that finding the roots of the transparency problem and the uprising pressure on public resources is necessary before any changes could be made.

One of the challenges for the theory is to suggest an administratively simple but transparent system for the decision making concerning grants. Under specific conditions, the voucher system can be a tool for improving transparency of the system. The challenge for the public sector is the implementation of this system. We conclude that inspiration could be found in alternative theories and comparisons of the best practices among Czech and other European countries. Considering that any implementation of such a system would be strictly voluntary (at least in the Czech Republic), we have to rely on the hope that most municipalities really want to maximize the positive effects of grant allocation. Questions like "How can we support sport through public budgets?" or "How can we increase the transparency of such support?" are still alive. If we ever want to improve sport support and achieve positive effects for society, we have to stop non-transparent grant allocation and consistently seek best practices. 


\section{References}

BROWN, L.D., KALEGAONKAR, A. (2002). Support Organizations and the Evolution of the NGO Sector. Nonprofit and Voluntary Sector Quarterly. June 2002 31: 231-258, DOI:10.1177/0899764002312004

Commission of the European Union (2007). White paper on sport. Retrieved June 15, 2012 from http://ec.europa.eu/sport/white-paper/doc/wp_on_sport_en.pdf

CROMPTON, J.L. (1983). Recreation Vouchers: A Case Study in Administrative Innovation and Citizen Participation. Public Administration Review; Nov/Dec83, Vol. 43, Issue 6, p. 537, 10p.

FRIEDMAN, M., FRIEDMAN, R. (1982). Capitalism and freedom. Chicago: University of Chicago Press, 1982, xi, 202 s. ISBN 0226264009.

GORTER, A., SANDIFORD, P., ROJAS, Z., SALVETTO, M.(2003). Competitive Voucher Schemes for Health Background Paper. Instituto CentroAmericano de la Salud ICAS. Retrieved September 20, 2012 from http://www.doh.state.fl.us/Family/dental/OralHealthcareWorkforce/Call20080407/Com petitive Voucher.doc

JONES, C. (2002). Public cost for private gain? Recent and proposed 'national' stadium developments in the UK, and commonalities with North America. Area, 34: 160-170. DOI: $10.1111 / 1475-4762.00068$

KANTOR, P. (1995). The dependent city revisited: The political economy of urban development and social policy. Boulder, CO: Westview. ISBN 081331903X.

MARTIN, F. (2001). Should Cities Subsidize Nonprofit International Organizations?: A Case Study and Cost Benefit Analysis. Journal of Urban Affairs, vol. 23, pp. 361-373. DOI: 10.1111/0735-2166.00094.

NEMEC, J., MEDVED, J., ŠAGÁT, V. (2009) Public finance and sports in Slovakia, selected problems and their developments under the economic and financial crisis. In: Teoretické a praktické aspekty VF. VŠE Praha, 2009.

PEACOCK, S., SEGAL, L. (2000). Capitation funding in Australia: imperatives and impediments. Health Care Management Science. 3(2):7788.DOI:10.1023/A:1019037206624

STIRTON, L., LODGE, M. (2001). Transparency Mechanisms: Building Publicness into Public Services. Journal of Law and Society, 28: 471-489. DOI: 10.1111/14676478.00199 .

Transparency international (2009). Global corruption barometer. Retrieved September 20, 2012 from http://www.transparency.cz/doc/global_corruption_barometer_2009_web.pdf

VALKAMA, P., BAILEY, S.J. (2001). Vouchers As an Alternative Public Sector Funding System. Public Policy and Administration. Spring 2001 16: 32-58, DOI:10.1177/095207670101600103. 
WILSON, J. (1999). Acknowledging the expertise of patients and their organisations. $B M J$ Vol 319, pp 771- 774. DOI:10.1136/bmj.319.7212.771

WOLMAN, H., SPITZLEY, D. (1999). The politics of local economic development. In J. Blair \& L. Reese (Eds.), Approaches to economic development: Readings from Economic Development Quarterly (pp. 225-263). Thousand Oaks, CA: Sage. DOI: 10.1177/089124249601000201.

\section{Information gathered about vouchers practice (Accessed 2012/09/21)}

Hodonín $(2012 ; 1)$ Zásady přidělování dotací na činnost organizací provozujících veřejněprospěšnou činnost. Retrieved September 21, 2012 from www.hodonin.eu/VismoOnline_ActionScripts/File.ashx?id_org=4041\&id_dokumenty= $\underline{1054449}$

Hodonín $(2012 ; 4)$ Zavedení systému přidělování dotací sportovním oddílům formou grantových poukázek. Retrieved September 21, 2012 from http://www.google.cz/url?sa=t\&rct=j\&q=transparentnost\%20rozd\%C4\%9Blov\%C3\%A $\underline{1 \mathrm{n} \% \mathrm{C} 3 \% \mathrm{AD} \% 20 \mathrm{dotac} \% \mathrm{C} 3 \% \mathrm{AD} \& \text { source }=\text { web\&cd=3\&cad=rja\&ved=0CCsQFjAC\&ur }}$ 1=http\%3A\%2F\%2Fwww.mvcr.cz\%2Fsoubor\%2Fmanak-hodonin-grantove-poukazkyrezim-kompatibility-

pdf.aspx\&ei=I4dZUNSfDabY4QSEyYDIAw\&usg=AFQjCNEUA8c2E3SzFAUPiVdv UEXyk3mmsg

Opava(2012; 1) Granty statutární město Opava. Retrieved September 21, 2012 from http://www.cstvopava.cz/oscstv-informace-pro-vas-granty-opava

Opava $(2012 ; 2)$ Granty 2012 - vyhodnocení poukázkového systému. Retrieved September 21, 2012 from

http://www.google.cz/url?sa=t\&rct=j\&q=opava\%20grantov\%C3\%BD\%20pouk\%C3\%A1zkov\% C3\%BD\%20syst $\%$ C3\%A9m\&source=web\&cd $=4 \&$ ved $=0 \mathrm{CFgQFj}$ AD\&url $=\mathrm{http} \% 3 \mathrm{~A} \% 2 \mathrm{~F} \% 2 \mathrm{Fww}$ w.op4u.cz\%2Fpub\%2Fzmo\%2FZ_120423_010\%2Fz_010_021\%2Fz_010_021_000.doc\&ei=jHf KT_iGNMSUOpO56e8P\&usg=AFQjCNF5hJFyGK3zBhhSjmmvKwaCVx8zFA

Opava (2013;1) Zásady poskytování grantů. Retrieved January, 15, 2013 fromwww.opava-city.cz/assets/zx/radnice/granty/granty2013/zasady.doc

Poděbrady $(2012 ; 1)$ Zásady městka Poděbrady pro poskytování dotací v oblasti volnočasových aktivit. Retrieved September 21, 2012 from www.mestopodebrady.cz/VismoOnline_ActionScripts/File.ashx?id_org=12349\&id_dokumenty=58 $\underline{80}$

BURSA, P (2012) Materiál o možné metodě financování základních sportovních aktivit dětí a mládeže ve věkové kategorii 6.-19. Let (Prostějov). Retrieved September 21, 2012 from http://www.pavelbursa.cz/sport.pdf

Hodonín (2012; 2) Hodonínské listy 06/2012. Retrieved September 21, 2012 from www.hodonin.eu/VismoOnline_ActionScripts/File.ashx?id_org=4041\&id_dokumenty= $\underline{1058759}$

Hodonín (2012; 3) Deník.cz: Hodonín rozdělil sportovní mládež 2,5mil. Kč. Retrieved September 21, 2012 from http://hodoninsky.denik.cz/zpravy_region/hodonin-rozdelilsportovni-mladezi-dva-a-pul-milionu-20120531.html 